\title{
Multimedia English Learning Materials for Deaf or Hard of Hearing (DHH) Children
}

\author{
Ni Luh Putu Sri Adnyani ${ }^{*}$, Ni Made Rai Wisudariani ${ }^{2}$, Gede Aditra Pradnyana ${ }^{3}$, I \\ Made Ardwi Pradnyana ${ }^{4}$, Ni Komang Arie Suwastini ${ }^{5}$ (D) \\ 1,2,5 Prodi Pendidikan Bahasa Inggris, FBS, Universitas Pendidikan Ganesha, Singaraja, Indonesia \\ ${ }^{3,4}$ Prodi Sistem Informatika, FTK, Universitas Pendidikan Ganesha, Singaraja, Indonesia
}

\section{A R T I C L E I N F O}

Article history:

Received August 12, 2021

Revised August 16, 2021

Accepted October 12, 2021

Available online November 25, 2021

\section{Kata Kunci:}

DHH, Multimedia, Bahasa Inggris

Keywords:

DHH, Multimedia, English, Learning Materials

DOI:

https://dx.doi.org/10.23887/jet.v5i4.3 8829

\begin{abstract}
A B S T R A K
Dalam mendukung pembelajaran bagi anak Tunarungu/ Sulit Mendengar /DHH, tidak mudah menemukan sumber belajar yang dapat diakses secara online, khususnya dalam bahasa Inggris. Selain itu, di masa pandemi COVID-19 ketika pembelajaran harus dilakukan secara online, belum ada aplikasi pembelajaran yang menyertakan bahasa isyarat bahasa Inggris yang dapat digunakan oleh guru dan siswa sebagai media pembelajaran. Dengan demikian, penelitian ini bertujuan untuk menganalisis kebutuhan pengembangan materi pembelajaran bahasa Inggris berbasis multimedia untuk anak Tunarungu atau Sulit Mendengar (DHH). Penelitian kualitatif ini melibatkan siswa dan pengajar DHH di Sekolah Luar Biasa (SLB) di Bali. Analisis kebutuhan dilakukan untuk mengidentifikasi situasi berkelanjutan anak DHH dalam konteks pengembangan materi pembelajaran multimedia bahasa Inggris. Teknik wawancara dan observasi dengan menggunakan dua jenis instrumen berupa pedoman wawancara dan catatan lapangan digunakan untuk mengumpulkan informasi tentang kebutuhan belajar bahasa Inggris untuk anak DHH. Hasil penelitian mengidentifikasi beberapa kebutuhan yang mendasari pengembangan materi pembelajaran multimedia bahasa Inggris, yaitu instruktur bahasa Inggris yang tidak memadai, bahan ajar berbasis teks, dan proses belajar mengajar yang kurang optimal selama pandemi COVID-19. Oleh karena itu, pengembangan materi pembelajaran bahasa Inggris berbasis multimedia sangat diperlukan. Salah satu bahan ajar yang dapat dikembangkan adalah kamus bahasa isyarat berbasis aplikasi mobile.
\end{abstract}

\section{A B S T R A C T}

In supporting learning for Deaf or Hard of Hearing/DHH children, it is not easy finding learning sources that are accessible online, especially in English. Furthermore, during the COVID-19 pandemic, when learning was required to be carried out online, there were no learning applications that included English sign language that could be used by teachers and students as learning media. Thus, this study aims to analyze the need for developing multimedia-based English learning materials for Deaf or Hard of Hearing (DHH) children. This qualitative study involved DHH students and instructors in Special School (SLB), Bali. The need analysis was conducted to identify the ongoing situation of DHH children in the context of developing English multimedia learning materials. Interview and observation techniques applying two types of instruments in the form of an interview guide and field notes were used to collect the information towards the English learning needs for DHH children. The results of the study identified several needs that underlie the development of English multimedia learning materials, namely inadequate English instructors, text-based teaching materials, and the less than optimal teaching and learning process during the COVID-19 pandemic. Therefore, the development of multimedia-based English learning materials is needed.

This is an open access article under the $\underline{C C B Y-S A}$ license. Copyright (C) 2021 by Author. Published by Universitas Pendidikan Ganesha.

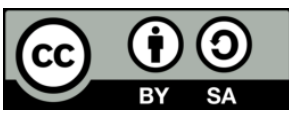

\section{INTRODUCTION}

The national language policy mandates Indonesian people to be multilingual, with an emphasis on the usage of Indonesian, the preservation of regional languages, and foreign language proficiency (Bedir, 2019; Fauyan, 2019). This policy provides a solid foundation for language development in all settings, including schools for students with special needs. However, the facts in Bali special needs schools indicate that students' expectations of being able to be a good multilingual have not been met to the greatest extent possible because (1) 
the majority of students exposed to sign language are Indonesian, resulting in a lack of mastery of other languages, and (2) the learning system used is still textbook-based. The facts show the critical need for enhancements in language learning for children with disabilities. Education in the era of revolution 4.0 demands educators to be able to utilize the outcomes of technological advancements as a source of learning, as highlighted by the Minister of Education and Culture's call at the ISODEL international symposium. Particularly in the Covid-19 pandemic, where learning is conducted online (Binali et al., 2021; Friedman \& Friedman, 2013; Yulia, 2020). It is critical to utilize technology to assist deaf and hard of hearing children (Jabar \& Ahmad, 2018). Children who are deaf or hard of hearing (DHH) are visual learners who rely on sight to receive information (Chen, 2014; Pariyatin \& Ashari, 2014). As a result, they require visual representations of instructional materials (Hopkins \& Moore, 2010; Malatista \& Sediyono, 2010).

In supporting learning for DHH, parents found it difficult to find programs easily accessible online (Kritzer \& Smith, 2020). While multimedia-based learning apps such as Ruang Guru, Rumah Belajar, Google Classroom, Sekolahmu, and Zenius are freely available, they are designed for average students only (Albashtawi \& Al Bataineh, 2020; Alimin \& Saad, 2019; Khalil, 2018). The portal is not accessible to DHH children. The mobile application for DHH children is only available in the form of i-CHAT launched by PT. Telekomunikasi Indonesia, Tbk. However, the i-CHAT app only introduced monolingual sign language, namely Indonesian sign language. The previous studies found that there has been no instructional application that includes English sign language introduced to DHH children in Bali. Furthermore, previous studies in language and learning areas have been mostly focused on normal growing children-very limited studies aimed at assisting students with disabilities, especially DHH children (Abdulhalim et al., 2021; Quinto-Pozos, 2011). Also, none of the studies have developed learning materials that include the English language introduced to DHH children (Gayathri \& Sasi Kumar, 2017; Handhika et al., 2018; Supriyati \& Iqbal, 2013). Thus, the need for children to be introduced to language signs as early as possible cannot be met. The Covid-19 pandemic also requires distance learning which facilitates visual learning in learning English.

The effort to make it happen is to develop appropriate resources for English learning that can provide multimedia-based learning by combining visuals and technology in a mobile application. In accordance with this, the development of multimedia-based teaching materials in Indonesian and English Sign Language is the essential solution to be developed in education. Multimedia combines two or more media elements consisting of text, graphics, images, photos, audio, and animation in an integrated manner (Fauyan, 2019; Lauc et al., 2020; Lee \& Osman, 2012). Interactive multimedia is multimedia equipped with a controller that the user can operate to choose what to do for the following process (Khan \& Masood, 2015; Leszczyński et al., 2018; Weng et al., 2018). The benefits that can be obtained are that the learning process is more interesting, more interactive, the amount of teaching time can be reduced, the quality of learning can be improved, and the learning process can be done anywhere and anytime, and student learning attitudes can be improved (Majid et al., 2012; Marnita \& Ernawati, 2017). In addition, multimedia can present objects or events that are complex, complicated, and take place sooner or later (Komalasari \& Rahmat, 2019; Primamukti \& Farozin, 2018).

The findings of previous research stated that multimedia could help students learn (Khamparia \& Pandey, 2017; Laksana et al., 2019; Riyanto \& Gunarhadi, 2017). Other research findings also state that learning multimedia can increase students' motivation in learning and can improve student learning outcomes (Andini et al., 2018; Indah Septiani et al., 2020; Kalyuga, 2012). Therefore, in this study, a multimedia English learning material was developed, which can supplement teaching materials for DHH children. The novelty of the research lies in the use of the theoretical basis of cognitive development on DHH children, where they need to be introduced to language signs as early as possible. Besides, the present study explored the importance of developing multimedia learning materials for DHH children, which have not been explored by the previous studies. The product in the form of a sign language dictionary application developed in this study was expected to be able to facilitate $\mathrm{DHH}$ children in acquiring sign language from an early age.

\section{METHOD}

This study applied descriptive qualitative research to gather in-depth information about the English teaching and learning process conducted in SLB Bali for DHH children. In order to identify the learning needs for them, need analysis was done combining Target Situation Analysis (TSA) and Present Situation Analysis (PSA). TSA was applied to collect the information about the tasks and activities in which English is used, while PSA was applied to identify the students' current language skills. The result of the analysis was described in the form of a narrative. This research design enables researchers to look for factual information in detail and identify the ongoing problems faced by DHH children in learning English in order to develop English multimedia learning materials.

This study involved 25 DHH students and three classroom instructors in SLB B Negeri 1 Buleleng, Bali. This school was chosen considering that this school in Buleleng facilitates children with special needs such 
as DHH children to take formal education like other normal children. Thus, the school may struggle in developing the learning materials, especially for English subject. Interview and observation techniques were used to collect the information towards the English learning needs for DHH children in SLB B Negeri 1 Buleleng. Two types of instruments in the form of an interview guide and field notes were applied. The blueprint of the interview guide can be seen in table 1 .

Table 1. The Blueprint of Interview Guide

\begin{tabular}{clcl}
\hline No. & \multicolumn{1}{c}{ Topic } & \multicolumn{1}{c}{ Ttem } & \multicolumn{1}{c}{ Types of Questions } \\
\hline 1 & $\begin{array}{l}\text { The instructor of } \\
\text { English language } \\
\text { teaching } \\
\text { The curriculum and } \\
\text { teaching materials used } \\
\text { in teaching English } \\
\text { The teaching-learning } \\
\text { process during the }\end{array}$ & $4,5,6$ & $\begin{array}{l}\text { The questions include the number of instructors of English } \\
\text { language teaching and their educational background }\end{array}$ \\
$\begin{array}{l}\text { Covid-19 pandemic questions include curriculum applied in teaching } \\
\text { The possibility of using } \\
\text { multimedia learning } \\
\text { materials in teaching } \\
\text { English }\end{array}$ & $\begin{array}{l}\text { DHH children } \\
\text { The questions include how the teaching and learning } \\
\text { processes were conducted during the Covid-19 pandemic } \\
\text { and the challenges faced } \\
\text { The questions include teachers' opinions towards the } \\
\text { importance of using multimedia learning materials for } \\
\text { teaching English for DHH children and the benefits of } \\
\text { visual learning. }\end{array}$ \\
\hline
\end{tabular}

Table 1 presents the interview guide used in collecting information towards the English learning needs for DHH children in SLB B Negeri 1 Buleleng. The steps in collecting the data include; interviewing the instructors towards the English teaching-learning process in SLB B Negeri 1 Buleleng, taking filed notes toward the information found during observation, identifying English learning needs based on the data, describing the data so that it can answer the existing problems, drawing a conclusion based on the result of the findings. The data analysis flows followed Miles and Huberman (1984), consisting of data reduction, data display, and conclusion drawing. In data reduction, the researchers eliminated unnecessary information from the transcribed interview and focused only on the information related to the learning process, the learning materials, and the learning platforms used in the English teaching and learning process for DHH children. The data then were described that enables conclusion drawing toward the English learning needs of DHH children. Finally, the conclusion was drawn based on the result of the interview and observation.

\section{RESULT AND DISCUSSION}

\section{Result}

Based on the result of the interview, it was found that the students in SLB B Negeri 1 Singaraja are considered DHH children. Students who experience difficulties during the learning process due to physical, emotional, mental, intellectual, and/or social disorders are categorized as students with disabilities (Calhoon et al., 2010; Kemp, 2017; Kkese, 2020). The characteristics of DHH children can be seen in terms of normal and average intelligence, barriers to hearing and communication, emotional imbalance, and is closed to the outside world. The present study discovered several findings in terms of the instructor, learning materials, and teachinglearning process thus, the need to develop English multimedia learning materials for DHH children. The findings were explained as follows. Based on the result of the analysis, it was found that there is no instructor who specializes in teaching English. The instructor for English language teaching is the classroom teacher. They are teachers who deal with students as a whole class in a classroom. They are in charge of each student's overall academic program as well as teaching the core curriculum in their role as a general education instructor (literacy, mathematics, science, social studies, and so forth). Thus, the classroom teachers might not have adequate knowledge of teaching techniques and strategies in terms of the language input for students during their classroom learning. They might struggle for knowledge of the organization of ideas, the use of grammar, and a limited range of vocabulary.

Educating students with severe disabilities in segregated educational environments were found to be more effective. To ensure that DHH children are not marginalized, an education system should establish ASLbased services. The result of the need analysis also found that the teachers designed their own curriculum and syllabus based on the characteristics of their students. One of the core competencies listed in the lesson plan is focusing students on possessing a skill in presenting factual knowledge in clear language, systematic, and logical, in aesthetic work, in movement that reflects a healthy child, and in actions that reflect the behavior of 
children of faith and noble character. Five basic competencies were highlighted in the lesson plan that enables students to; 1) express greetings, goodbyes, thanks, and apologies, and the response, 2) expressing simple text for introductory expressions and the response, 3) ask and give information about the description of objects found at home, school and playground, 4) state and ask for the date, day, month and year, and 5) state the names of the members of the human body. It was found that the teaching materials are still textbook-based. Teaching materials are a key instrument in most language courses.

The outbreak of the COVID-19 has resulted in the policy by the Indonesian Ministry of Education and Culture in Surat Edaran Nomor 4 tahun 2020 to close schools and universities where the students learn from home due to the number of reported cases suggests that the gathering of people in a single place for a period of time increases the risk of infection. Emergency remote learning has been implemented where the teaching and learning were conducted in online classrooms through synchronous and asynchronous learning, which cause the interactions between students and lecturers to be limited by the distance. This condition also affected the teaching-learning process in SLB B Negeri 1 Singaraja. During the COVID-19 pandemic, the English teachinglearning process was conducted online using platforms such as Google Meet, Zoom, and WhatsApp chat. These platforms were used interchangeably considering the students' ability to access the internet and purchase data packages or quotas. They were also struggling in finding appropriate e-learning that facilitates their teachinglearning activities. It was found that e-learning does not provide sign language, which raises institutional support and existing social inequalities.

Sign language is important to be taught as early as possible to DHH since the ability of DHH in using sign language correlates with reading and writing skills general language skills (Andrew et al., 2014; Henner et al., 2019). Furthermore, the use of multimedia can help deaf and speech impaired children enhance their communication skills and social integration (Lee \& Osman, 2012; Rubini et al., 2018). Multimedia facilitates learning and enables teachers to teach DHH children more effectively. Additionally, the utilization of multimedia makes learning more appealing than traditional approaches. Due to their hearing impairment, deaf children have difficulties comprehending instruction. DHH children will benefit from multimedia because it assists in transmitting information to them. Additionally, multimedia can be adapted to the learning principles of DHH children through the use of audio, video, and technology in order to instill a passion for learning and improve the learning process. Considering the importance of introducing sign language at an early age, this study developed a mobile application of an English sign language dictionary combining visual and multimedia learning materials. The steps in developing the product can be seen in figure 1 .

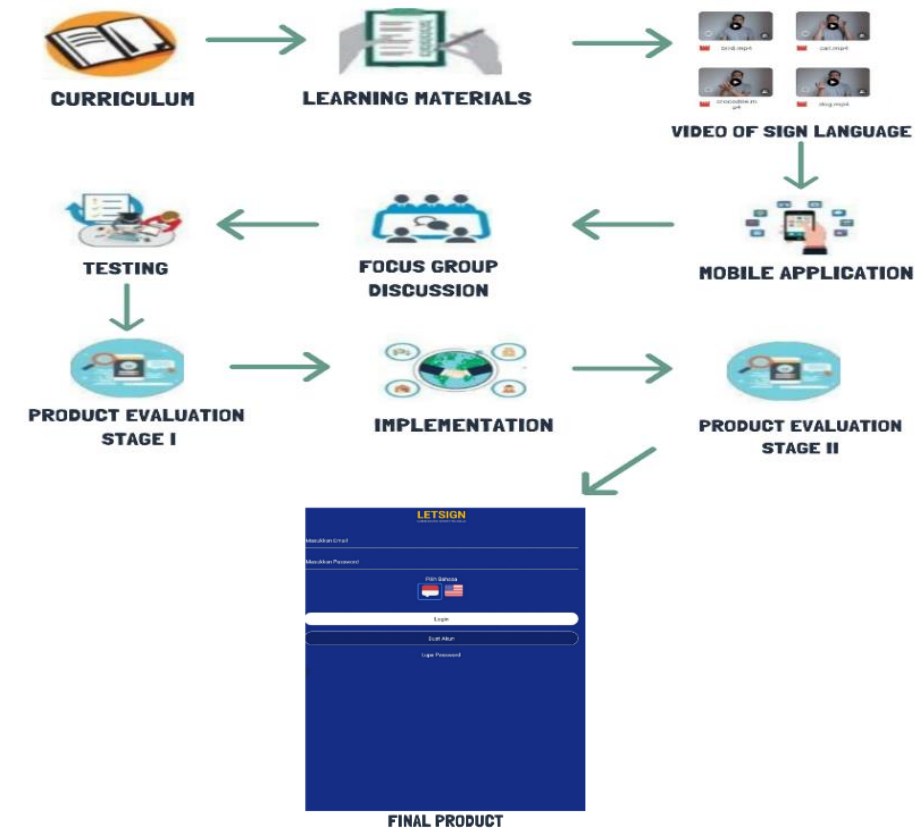

Figure 1. The flowchart of developing English multimedia learning materials for DHH children

Figure 1 shows ten steps in developing English multimedia learning materials in the form of an English sign language dictionary. The first step was analyzing the curriculum applied in SLB B Negeri 1 Singaraja. It includes analyzing the syllabus, lesson plan, learning materials, learning sources, and characteristics of the students. This step enables the researchers to identify the learning needs of the DHH children, their hearing, 
thinking development level, language ability level, and technological literacy. The second step was designing learning materials. There are 13 topics included in the dictionary which covers the materials for one semester. The third step was making a video of English sign language. The native American Sign Language (ASL) signer was recorded when demonstrating the vocabularies including in the 13 topics. The fourth step was designing a mobile application for an English sign language dictionary. The recorded videos were input into the application. After that, the fifth step was conducting a focus group discussion. The researchers, along with the expertise, discussed the prototype of the mobile application product considering four aspects; the content, the sign language, the multimedia, and the design of the dictionary. The sixth step was testing the product. The prototype of the dictionary was tested by the experts. The seventh step was conducting product evaluation stage I to get the result of validation from the expertise in content, sign language, multimedia, and dictionary design. The eighth step was implementation. The revised version of the product was implemented, limiting only to SLB B Negeri 1 Singaraja. The limited trial was aimed to gain feedback related to the practicality and effectiveness of the use of the dictionary. The ninth step was conducting product evaluation stage II. After revision, the last step was producing the final product. The final product was ready to be disseminated to stakeholders, in this case, the Bali Provincial Education Office.

\section{Discussion}

DHH children are also considered as 'visual learners' with auditory limitations who rely on sight to receive information (Holmer et al., 2016; Hoof et al., 2016; Marschark M, 2012). Compared to hearing persons, DHH children do have some visual-spatial benefits. They tended to rely mostly on pictorial representations and have superior visual-spatial working memory compared to hearing individuals (Alqraini \& Alasim, 2021; Soucie et al., 2021). Thus, to facilitate communication and instruction with DHH children, educators should provide visually stimulating learning environments included in signs, learning equipment, and materials (Blakely et al., 2020). Visual media itself is an item or material that takes the form of lines, colors, shapes, and spaces that is intended to convey a message to the audience. In this present study, the use of videos of ASL signer demonstrating some English vocabularies helps DHH children to adjust their learning styles that are usually visual and kinesthetic. This is in line with the previous studies that recommended creating visual learning settings by exhibiting visual materials and aids such as images, graphics, posters, and videos in addition to the use of sign language, speech reading, visual scaffolding, and fingerspelling (Budiman, 2016; Fauzi et al., 2017; Vala et al., 2021). By providing visual image learning materials to DHH children as they learn English, they can improve their vocabulary mastery and comprehension. They can improve their vocabulary mastery by associating with real objects that are displayed in colored pictures and printed words.

DHH children require exposure to the language as early as possible. Children who are exposed to language will reach the expected developmental milestones (Murray et al., 2020; Ratajczak, 2018; Veselova et al., 2021). Thus, the use of this mobile application at an early age could avoid them from the risk of developing delayed language skills throughout their lives. Thus, integrating interactive learning media into the lesson, especially for the delivery of learning materials, will make it easier and more pleasant for DHH children to learn English. This will also make the learning process more interesting and will prevent them from becoming bored. The use of appealing English multimedia learning materials could also improve the autonomous learning of DHH children. Due to the presence of appealing learning media, their motivation to learn will grow, and their level of concentration towards the subject matter will increase, which will have an impact on the overall quality of education (Jayanegara et al., 2020; Leszczyński et al., 2018; Majid et al., 2012; Samri et al., 2020). The use of multimedia engages the senses, stimulates their attention, and helps them retain information better. It also advances language skills such as comprehension, spoken language and vocabulary, expressions in spoken language, reading capacities, and writing abilities (Dashtestani, 2013; Fauyan, 2019; Kembara et al., 2018; Sert \& Boynueğri, 2017). Therefore, the final product of this present study supported previous research on the development systems and multimedia in assisting DHH children in the learning process, including the android application to allow DHHs children to communicate with the general public. The development of programs to detect body language, Indonesian sign language (Bisindo) and the development of Indonesian sign systems

\section{CONCLUSION}

In conclusion, from the result of the analysis, this present study identified several reasons for developing English multimedia learning material. The reasons are inadequate English instructors, the curriculum and teaching materials, the teaching and learning process during the COVID-19 pandemic. Thus, English multimedia learning material in the form of an English sign dictionary mobile app is needed. The development of multimedia learning materials benefits DHH children in the aspect of visual learning and multimedia. 


\section{REFERENCES}

Abdulhalim, I., Mutch, C., González, V. A., \& Amor, R. (2021). Improving post-earthquake evacuation preparedness for deaf and hard of hearing children: A conceptual framework. International Journal of Disaster Risk Reduction, 62. https://doi.org/10.1016/j.ijdrr.2021.102360.

Albashtawi, A. H., \& Al Bataineh, K. B. (2020). The effectiveness of google classroom among EFL students in Jordan: An innovative teaching and learning online platform. International Journal of Emerging Technologies in Learning, 15(11), 78-88. https://doi.org/10.3991/IJET.V15I11.12865.

Alimin, F. G., \& Saad, M. S. M. (2019). The Effectiveness of Google Classroom as an Instructional Media: A Case of State Islamic Institute of Kendari, Indonesia. Journal of Humanities and Social Sciences, 7(2). https://doi.org/10/18510/hssr.2019.7227.

Alqraini, F. M., \& Alasim, K. N. (2021). Distance Education for d/Deaf and Hard of Hearing Students during the COVID-19 Pandemic in Saudi Arabia: Challenges and Support. Research in Developmental Disabilities, 117. https://doi.org/10.1016/j.ridd.2021.104059.

Andini, S., Budiyono, \& Fitriana, L. (2018). Developing flipbook multimedia: The achievement of informal deductive thinking level. Journal on Mathematics Education, 9(2), 227-238. https://doi.org/10.22342/jme.9.2.5396.227-238.

Andrew, K. N., Hoshooley, J., \& Joanisse, M. F. (2014). Sign language ability in young deaf signers predicts comprehension of written sentences in English. PLOS ONE, 9(2). https://doi.org/10.1371/journal.pone.0089994.

Bedir, H. (2019). Pre-service ELT teachers' beliefs and perceptions on 21st century learning and innovation skills (4Cs). Journal of Language and Linguistic Studies, 15(1), 231-246. https://doi.org/10.17263/j1ls.547718.

Binali, T., Tsai, C.-C., \& Chang, H.-Y. (2021). University students' profiles of online learning and their relation to online metacognitive regulation and internet-specific epistemic justification. Computers \& Education, 175. https://doi.org/10.1016/j.compedu.2021.104315.

Blakely, M. L., McKnight, K. D., Darling, R. A., \& Moody, E. J. (2020). Using an OSCE to assess the potential for assistive technology to enhance communication between student pharmacists and simulated patients who are deaf/hard of hearing. Journal of the American Pharmacists Association, 60(6). https://doi.org/10.1016/j.japh.2020.08.031.

Budiman, H. (2016). Penggunaan Media Visual dalam Proses Pembelajaran. Jurnal Pendidikan Islam, 7(2), 171-182. https://doi.org/10.24042/atjpi.v7i2.1501.

Calhoon, M. B., Sandow, A., \& Hunter, C. V. (2010). Reorganizing the instructional reading components: Could there be a better way to design remedial reading programs to maximize middle school students with reading disabilities' response to treatment? Annals of Dyslexia, 60(1). https://doi.org/10.1007/s11881009-0033-X.

Chen, Y. T. (2014). A study to explore the effects of self-regulated learning environment for hearing-impaired student. Journal of Computer Assisted Learning, 30(2). https://doi.org/10.1111/jcal.12023.

Dashtestani, R. (2013). Implementing mobile-assisted language learning (MALL) in an EFL context: Iranian EFL teachers' perspectives on challenges and affordances. The JALT CALL Journal, 9(2), 149-168. https://doi.org/10.29140/jaltcall.v9n2.153.

Fauyan, M. (2019). Developing Interactive Multimedia Through Ispring on Indonesian Language Learning with The Insights of Islamic Values in Madrasah Ibtidaiyah. Al Ibtida: Jurnal Pendidikan Guru MI, 6(2), 177. https://doi.org/10.24235/al.ibtida.snj.v6i2.4173.

Fauzi, H. A., Komalasari, K., \& Malik, Y. (2017). Utilization of Audio Visual Media to Improve Student Learning Result in IPS Learning. International Journal Pedagogy of Social Studies, 2(1), 88-103. https://doi.org/10.17509/ijposs.v2i1.8666.

Friedman, L. W., \& Friedman, H. H. (2013). Using social media technologies to enhance online learning. Journal of Educators Online, 10(1). https://doi.org/10.9743/JEO.2013.1.5.

Gayathri, A., \& Sasi Kumar, A. (2017). Sign language recognition for deaf and dumb people using android environment. International Journal of Current Engineering and Scientific Research (IJCESR), 4. https://papers.ssrn.com/sol3/papers.cfm?abstract_id=3374759.

Handhika, T., Zen, R. I. M., Lestari, D. P., \& Sari, I. (2018). Gesture recognition for Indonesian sign language (BISINDO). In Journal of Physics: Conference Series, 1028(1). https://iopscience.iop.org/article/10.1088/1742-6596/1028/1/012173/meta.

Henner, J., Novogrodsky, R., Caldwell-Harris, C., \& Hoffmeister, R. (2019). The development of American Sign Language-based analogical reasoning in signing deaf children. Journal of Speech, Language, and Hearing Research, 62(1). https://doi.org/10.1044/2018_jslhr-1-18-0062.

Holmer, E., Heimann, M., \& Rudner, M. (2016). Evidence of an association between sign language phonological 
awareness and word reading in deaf and hard-of-hearing children. Research in Developmental Disabilities, 46. https://doi.org/10.1016/j.ridd.2015.10.008.

Hoof, L. van B., Hermans, D., Knoors, H., \& Verhoeven, L. (2016). Benefits of augmentative signs in word learning: Evidence from children who are deaf/hard of hearing and children with specific language impairment. Research in Developmental Disabilities, 59. https://doi.org/10.1016/j.ridd.2016.09.015.

Hopkins, K., \& Moore, B. C. (2010). The importance of temporal fine structure information in speech at different spectral regions for normal-hearing and hearing-impaired subjects. The Journal of the Acoustical Society of America, 127(3). https://doi.org/10.1121/1.3293003.

Indah Septiani, A. nisa N. S., Septiani, I., Rejekiningsih, T., Triyanto, \& Rusnaini. (2020). Development of interactive multimedia learning courseware to strengthen students' character. European Journal of Educational Research, 9(3), 1267-1279. https://doi.org/10.12973/eu-jer.9.3.1267.

Jabar, S. A., \& Ahmad, A. (2018). The design of multimedia interactive courseware for teaching reading to hearing impaired students. International Journal of Academic Research in Progressive Education and Development, 7(4). https://doi.org/10.6007/IJARPED/v7-i4/4849.

Jayanegara, I. N., Setiawan, I. N. A. F., \& Putri, G. A. M. (2020). Design of interactive multimedia learning vocabulary for students communication disorder and deafness during the Covid-19 pandemic. IJDS: Indonesian Journal of Disability Studies, 7(2).

Kalyuga, S. (2012). Interactive distance education: A cognitive load perspective. Journal of Computing in Higher Education. https://doi.org/10.1007/s12528-012-9060-4.

Kembara, Rozak, \& Hadian. (2018). Research-based Lectures to Improve Students' 4C (Communication, Collaboration, Critical Thinking, and Creativity) Skills. Proceedings of the Second Conference on Language, Literature, Education, and Culture (ICOLLITE), 1(1). https://doi.org/10.2991/icollite$18.2019 .50, .20019 .11$.

Kemp, S. E. (2017). RAP: A reading comprehension strategy for students with learning disabilities and concomitant speech language impairments or ADHD. Journal of Education and Training, 4(2). https://doi.org/10.5296/jet.v4i2.11614.

Khalil, Z. M. (2018). EFL Students' Perceptions towards Using Google Docs and Google Classroom as Online Collaborative Tools in Learning Grammar. Applied Linguistics Research Journal, 2(2), 33-48. https://doi.org/10.14744/alrj.2018.47955.

Khamparia, A., \& Pandey, B. (2017). Impact of interactive multimedia in E-learning technologies: Role of multimedia in E-learning. Enhancing Academic Research With Knowledge Management Principles, April, 199-227. https://doi.org/10.4018/978-1-5225-2489-2.ch007.

Khan, F. M. A., \& Masood, M. (2015). The Effectiveness of an Interactive Multimedia Courseware with Cooperative Mastery Approach in Enhancing Higher Order Thinking Skills in Learning Cellular Respiration. Procedia - Social and Behavioral Sciences, 176, 977-984. https://doi.org/10.1016/j.sbspro.2015.01.567.

Kkese, E. (2020). McGurk effect and audiovisual speech perception in students with learning disabilities exposed to online teaching during the COVID-19 pandemic. Medical Hypotheses, 144(July), 110233. https://doi.org/10.1016/j.mehy.2020.110233.

Komalasari, K., \& Rahmat, R. (2019). Living Values Based Interactive Multimedia in Civic Education Learning. International Journal of Instruction, 12(1), 113-126. https://doi.org/10.29333/iji.2019.1218a.

Kritzer, K. L., \& Smith, C. E. (2020). Educating deaf and hard-of-hearing students during COVID-19: What parents need to know. The Hearing Journal, 73(8).

Laksana, D. N. L., Dasna, I. W., \& Degeng, I. N. S. (2019). The effects of inquiry-based learning and learning styles on primary school students' conceptual understanding in multimedia learning environment. Journal of Baltic Science Education, 1(1). https://doi.org/10.33225/jbse/19.18.51.

Lauc, T., Jagodić, G. K., \& Bistrović, J. (2020). Effects of Multimedia Instructional Message on Motivation and Academic Performance of Elementary School Students in Croatia. International Journal of Instruction, 13(4), 491-508. https://doi.org/10.29333/iji.2020.13431a.

Lee, T. T., \& Osman, K. (2012). Interactive Multimedia Module in the Learning of Electrochemistry: Effects on Students' Understanding and Motivation. Procedia - Social and Behavioral Sciences, 46. https://doi.org/10.1016/j.sbspro.2012.05.295.

Leszczyński, P., Charuta, A., Łaziuk, B., Gałązkowski, R., Wejnarski, A., Roszak, M., \& Kołodziejczak, B. (2018). Multimedia and Interactivity in Distance Learning of Resuscitation Guidelines: A Randomised Controlled Trial. Interactive Learning Environments, 26(2), 151-162. https://doi.org/10.1080/10494820.2017.1337035.

Majid, M. S. Z. B. A., Ali, M. M. B. A., Rahim, A. A. B. A., \& Khamis, N. Y. B. (2012). The Development of Technical English Multimedia Interactive Module to Enhance Student Centered Learning (SCL). Procedia - Social and Behavioral Sciences, 67, 345-348. https://doi.org/10.1016/j.sbspro.2012.11.337. 
Malatista, B. R., \& Sediyono, E. (2010). Model pembelajaran matematika untuk siswa kelas IV SDLB penyandang tunarungu dan wicara dengan metode komtal berbantuan komputer. 7(1), 219382. Jurnal Teknik Informatika Dan Sistem Informasi, 7(1). https://doi.org/10.6007/IJARPED/v7-i4/4849.

Marnita, \& Ernawati. (2017). The Use of Interactive Multimedia (Macromedia Flash) to Increase Creative Thinking Ability of Students in Basic Physics Subject. Jurnal Pendidikan Fisika Indonesia, 13(2), 7178. https://doi.org/10.15294/jpfi.v13i2.10152.

Marschark M, K. H. (2012). Educating deaf children: Language, cognition, and learning. Deafness and Education International, 14(1). https://doi.org/10.1179/1557069X12Y.0000000010.

Murray, J. J., Hall, W. C., \& Snoddon, K. (2020). The importance of signed languages for deaf children and their families. The Hearing Journal, 73(3). https://doi.org/10.1097/01.HJ.0000657988.24659.f3.

Pariyatin, Y., \& Ashari, Y. Z. (2014). Perancangan media pembelajaran interaktif mata pelajaran PKN untuk penyandang tunarungu berbasis multimedia (Studi Kasus di Kelas VII SMPLB Negeri Garut Kota). Jurnal Algoritma, 11(1). https://doi.org/10.33364/algoritma/v.11-1.1.

Primamukti, A. D., \& Farozin, M. (2018). Utilization of interactive multimedia to improve learning interest and learning achievement of child. Jurnal Prima Edukasia, 6(2), 111-117. https://doi.org/10.21831/jpe.v6i2.19183.

Quinto-Pozos, D. (2011). Teaching American sign language to hearing adult learners. Annual Review of Applied Linguistics, 31. https://doi.org/10.1017/S0267190511000195.

Ratajczak, M. (2018). Language and value: the philosophy of language in the post-Operaist critique of contemporary capitalism. Language Sciences, 17. https://doi.org/10.1016/j.langsci.2018.08.004.

Riyanto, W. D., \& Gunarhadi, G. (2017). The Effectiveness of Interactive Multimedia in Mathematic Learning: Utilizing Power Points for Students with Learning Disability. IJPTE: International Journal of Pedagogy and Teacher Education, 1(1), 55-63. https://doi.org/10.20961/ijpte.v1i1.8400.

Rubini, B., Permanasari, A., \& Yuningsih, W. (2018). Learning Multimedia Based on Science Literacy on the Lightning Theme. Jurnal Penelitian Dan Pembelajaran IPA, 4(2), 89-104. https://doi.org/10.30870/jppi.v4i2.3926.

Samri, F., Rewo, J. M., \& Laksana, D. N. . (2020). Electronic Thematic Teaching Multimedia with Local Culture Based Materials and Its Effect on Conceptual Mastery of Primary School Students. European Journal of Education Studies, 7(2), 625-641. https://doi.org/10.46827/ejes.v7i12.3474.

Sert, N., \& Boynueğri, E. (2017). Digital technology use by the students and english teachers and self-directed language learning. World Journal on Educational Technology: Current Issues, 9(1), 24. https://doi.org/10.18844/wjet.v9i1.993.

Soucie, J., Vandervoort, L., Adkins, L. E., \& Miller, S. (2021). Experiential education for the deaf or hard of hearing learner in a pharmacy curriculum. Currents in Pharmacy Teaching and Learning, 13(9). https://doi.org/10.1016/j.cptl.2021.06.025.

Supriyati, E., \& Iqbal, M. (2013). Recognition system of Indonesia sign language based on sensor and artificial neural network. Makara Journal of Technology, 17(1). https://doi.org/10.7454/mst.v17i1.1924.

Vala, R., Valova, M., Drazdilova, P., Krömer, P., \& Platos, J. (2021). Behaviour associated with the presence of a school sports ground: Visual information for policy makers. Children and Youth Services Review, 128. https://doi.org/10.1016/j.childyouth.2021.106150.

Veselova, I., Khimich, G., \& Terentieva, E. (2021). The role of foreign language internships in cultural enrichment and increasing motivation for Russian students to learn Spanish. Heliyon, 7(9). https://doi.org/10.1016/j.heliyon.2021.e08006.

Weng, C., Otanga, S., Weng, A., \& Cox, J. (2018). Effects of interactivity in E-textbooks on 7th graders science learning and cognitive load. Computers \& Education, 120, 172-184. https://doi.org/10.1016/j.compedu.2018.02.008.

Yulia, H. (2020). Online Learning to Prevent the Spread of Pandemic Corona Virus in Indonesia. ETERNAL (English Teaching Journal), 11(1). https://doi.org/10.26877/eternal.v11i1.6068. 